\title{
MDM2 Inhibitor AMG-232
}

National Cancer Institute

\section{Source}

National Cancer Institute. MDM2 Inhibitor AMG-232. NCI Thesaurus. Code C116624.

An orally available, piperidinone inhibitor of MDM2 (murine double minute 2), with potential antineoplastic activity. Upon oral administration, MDM2 inhibitor AMG-232 binds to MDM2 protein and prevents its binding to the transcriptional activation domain of the tumor suppressor protein p53. By preventing this MDM2-p53 interaction, the transcriptional activity of p53 is restored. This leads to p53-mediated induction of tumor cell apoptosis. MDM2, a zinc finger protein and a negative regulator of the p53 pathway, is overexpressed in cancer cells; it plays a key role in cancer cell proliferation and survival. 